\section{Argentine crisis raises questions over plans for Australian reactor}

Peter Pockley, Sydney

\& Virginia Gewin, Washington

Plans for Australia's largest-ever scientific facility - a research reactor to be built at Lucas Heights near Sydney — could be thrown into disarray because of Argentina's economic crisis, critics of the project claim.

Environmental groups in both Australia and Argentina say that INVAP, the publicly owned Argentine company contracted to build the facility, will not receive sufficient funds from its cashstrapped government to allow it to complete the five-year project.

But INVAP's chief executive, Héctor Otheguy, says that the company is financially sound and that this month's devaluation of the peso (see Nature 415, $104 ; 2002$ ) leaves INVAP in a stronger position. "As a company based on exports, the devaluation will be a plus, not a minus," he says, adding that the project is running on schedule. Costing A $\$ 290$ million (US\$150 million), the research reactor is scheduled to open in 2005.

Brendan Nelson, Australia's new science minister, agrees. "INVAP's activities under the contract are fully funded by the contract payments and are therefore not dependent on cash flow from the Argentine

government," he says.

But Raúl Montenegro, president of the Environment Defense Foundation, a pressure group based in Argentina, claims that INVAP relies on the Argentine government for cash flow, which is now drying up. "INVAP has no capacity for selffunding," he says.

A decision to license the reactor's construction is due next month after the project has been examined by the Australian Radiation Protection and Nuclear Safety Agency. One aspect the agency must consider is the viability of the plan to dispose of the reactor's spent fuel, which would be reprocessed by INVAP and stored at an unspecified site in South Australia.

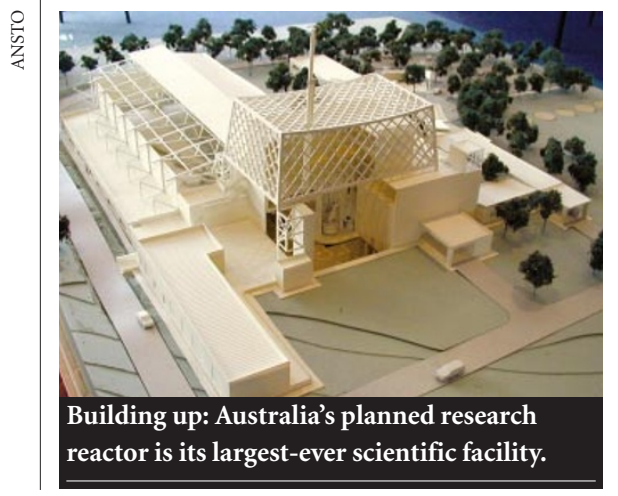

\title{
Expedition trawls sea bed for energy-rich gas crystals
}

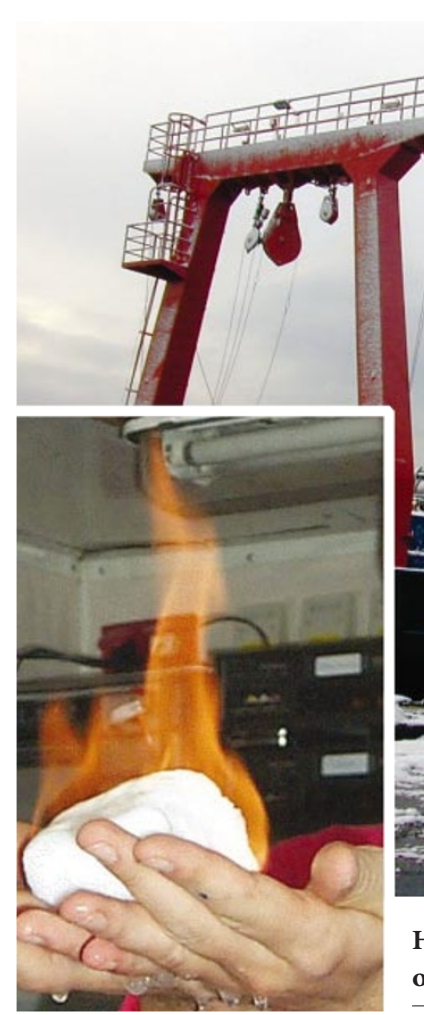

Quirin Schiermeier, Munich

An international team is this month scouring the floor of the Black Sea in an effort to gather more information on energy-rich methane hydrate crystals. Resembling ordinary ice, these structures are stuffed with natural gas and have been cited as a potentially massive source of energy.

Methane hydrate can form only at reasonably high pressures and low temperatures, and so is found mainly in the Arctic permafrost and on the sea bed along the edge of continental shelves. The volume of gas it contains gives it great potential as a fossil fuel - the US Department of Energy, for example, estimates that successfully tapping just $1 \%$ of existing methane hydrate could yield more energy than the world's entire reserves of natural gas.

Margasch, as the Black Sea expedition is known, is studying the structure and architecture of methane hydrate in sediments just below the sea bed. It plans to map their distribution and hopes to estimate the total quantity of hydrate available. It is also using video-guided tools to retrieve samples of the crystals.

"Its near-surface deposits make the Black Sea a preferable destination for studying hydrates," says expedition leader Gerhard Bohrmann, a geologist at the GEOMAR research centre in Kiel.

The team, which includes geophysicists, geochemists, biologists, oceanographers and meteorologists from Germany, France, Ukraine and Russia, left Istanbul on 2 January on the German research vessel Meteor.

The expedition has so far made good progress, Bohrmann reports. The scientists have already surveyed an active underwater mud volcano that releases methane, he says, and they hope that the data gathered will help them to test theories of how the hydrates form. They are also studying organisms that flourish at depths where the water contains no oxygen, surviving instead on methane.

Meteorologists, meanwhile, are interested in the influence that the hydrates might have on the composition of the atmosphere. Methane hydrate could be a significant source of atmospheric methane, an important greenhouse gas. Natural releases of the gas into the atmosphere could influence climate change, and German researchers aboard the ship are trying to establish how these releases occur.

The breakdown of the hydrates, triggered by changes in water pressure and temperature, is also thought to be responsible for seafloor landslides and large water waves (tsunamis). But most experts confess to being sceptical of the popular theory that they also sink ships in the foaming waters of the Bermuda Triangle.

t www.gashydrate.de/projekte/omega/margasch 